\title{
JUURNAL_RU
}

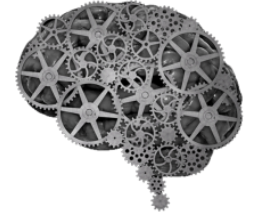

COMPANY GROUP "INTELLEKT"

Мелоян Е.К., Третьякова В.А., Тричева Е.В. Городская больнища № 1 им. Н.А. Семашко Детская городская поликлиника № 5 Городская поликлиника № 1 Ростов-на-Дону, Россия

doi: 10.18411/1j2016-5-2-16

\section{Применение фитопрепаратов в лечении хронического тонзиллита}

Хронический тонзиллит является одной из актуальных проблем оториноларингологии, что подтверждается данными о широкой распространенности заболевания среди всех групп населения независимо от возраста $[1,2]$. Поскольку нёбные миндалины выполняют важные иммунологические функции в организме, первостепенное значение в лечении хронического тонзиллита имеет органосохраняющая тактика.

Многочисленные методы патогенетически обоснованной консервативной терапии хронических воспалительных заболеваний органов лимфоглоточного кольца с применением иммуномодуляторов, детоксикации, антибиотиков, противовоспалительных и антиоксидантных препаратов не приводят к исчерпывающим результатам. Отношение к целесообразности хирургического лечения лимфоидной ткани остается неоднозначным [2, 3, 4]. Таким образом, значимость лимфоглоточного кольца для роста и развития детского организма и проблемы этой патологии остаются до конца не решенными, что требует дальнейшей разработки консервативных методов лечения. Совершенствование этих методов позволит предотвратить необходимость хирургического лечения до наступления возрастной инволюции лимфоидной ткани $[5,6,7]$. Оптимальными критериями при реализации оздоровительных программ должно 
быть следующее: доступность широкому кругу потребителей, удобство применения, отсутствие побочных действий, переносимость, комплексное действие.

Целью исследования являлись оценка эффективности применения фитопрепарата тонзилгон Н у детей с патологией лимфоглоточного кольца.

Материал и методы исследования. Под наблюдением находились 42 ребенка (18 мальчиков и 24 девочки), возраст больных варьировал от 7 до 16 лет.

Критериями включения детей в исследование являлись: наличие у детей гипертрофии небных миндалин I-III степени в сочетании с гипертрофией глоточных миндалин I-II степени, подтвержденное ЛОР-врачом; отсутствие признаков строго воспаления на момент начала исследования; добровольное согласие родителей на участие в исследовании.

Общеклиническая программа обследования включала общий и биохимический анализы крови, бактериологическое исследование мокроты и мазка с поверхности небных дужек и задней стенки глотки, анализ мокроты, оценку иммунного статуса.

Пациенты получали препарат Тонзилгон ${ }^{\circledR} \mathrm{H}$ в течение шести месяцев по 15-25 капель (в зависимости от возраста) три раза в день. Результаты терапии препаратом Тонзилгон ${ }^{\circledR}$ Н оценивали по окончании терапии и через год. Оценка результатов проводилась по балльной системе. Субъективные и объективные признаки оценивались по 3-алльной шкале: отсутствие патологических признаков оценивалось в 0 баллов, умеренно выраженный признак - 1 балл, начительно выраженный - 2 балла. Состояние лимфоидных органов оценивалось в соответствии со степенью величения миндалин: I степень - 2 балла, II степень - 4 балла, III степень - 6 баллов.

\section{Результаты.}

На момент начала исследования у всех детей общее состояние было значительно нарушено и составило 17,2+0,72 После первого курса лечения 
отмечено достоверное $(\mathrm{p}<0,05)$ улучшение в состоянии детей как субъективно, так и по объективным данным, что выражалось снижением среднего балла с 1714 до 7-8 баллов.

При последующих курсах лечения положительная динамика четко прослеживалась на протяжении всего периода наблюдения и к исходному уровню не возвращалась. Отмечено, что большая эффективность курсового лечения имела место у детей со II степенью гипертрофии небных миндалин, получающих комплексную терапию (ФТЛ и фитотерапию).

Современный фитопрепарат тонзилгон Н. способствует уменьшению гипертрофированных небных и глоточных миндалин, хорошо переносится детьми. Этот препарат может быть рекомендован в виде длительного курсового приема в качестве лечебно - профилактического средства для детей с патологией лимфокольца глотки с целью профилактики формирования хронических заболеваний верхних дыхательных путей как в виде монотерапии, так и в комплексе с методами ФТЛ. 


\section{Литература:}

1. Бойко Н.В., Бачурина А.С. Аденотомия и аденотонзиллотомия у детей с затруднением носового дыхания. Рос. ринология 2015; 23 (1): 9-12.

2. Бойко Н.В., Гукасян Е.Л., Быкова В.В. Статистика хирургических вмешательств при хроническом тонзиллте оториноларингологии 2008; 5: 234.

3. Бойко Н.В., Локшина Л.С., Сорока Г.Г., Бриж Ю.В., Сулина Н.Ю. Изменение подходов к лечению хронического тонзиллита в детском возрасте по материалам Ростовской ЛОР клиники. Вестн оторинолар. 2012; 5: 226.

4. Власова Т.М., Бойко Н.В. Рост числа постстрептококковых осложнений у больных хроническим тонзиллитом. Рос. оторинолар. 2015; S1: 45-47.

5. Привалова Т.Е., Шадрин С.А., Васильева С.Р. Лечебно-профилактическое применение современных фитопрепаратов при функциональной патологии лимфоглоточного кольца у дошкольников. Кубанский научный медицинский вестник. 2009. № 4. С. 41-45.

6. Бойко Н.В., Калинкина М.И., Горшкова Г.И. Консервативное лечение хронического тонзиллита. Детская оториноларингол. 2012. № 3. С. 22-24.

7. Бойко Н.В., Бачурина А.С., Оксенюк О.С., Колмакова Т.С. Лечение послеоперационного воспаления после тонзиллэктомии у детей. Педиатрия. Журнал им. Г.Н. Сперанского. 2016, т. 95, № 1. С. 93-96. 